\title{
Ethnobotanical Profiling of Tehsil Dhirkot District Bagh Azad Jammu and Kashmir
}

Shameen Arif1, Basharat Mahmood ${ }^{2 *}$, Sajjad Hussain ${ }^{3}$, Rizwan Taj Khan ${ }^{4}$, Zahid Mahmood Sarwar ${ }^{5}$, Abid Hussain $^{3}$, Humaira Kousar ${ }^{3}$, Muhammad Tariq-Khan ${ }^{2}$, Asim Shamim ${ }^{6}$, Muhammad Riaz Khan ${ }^{7}$, Zahid Hussain Khan $^{7}$, Khan Irfan Khans ${ }^{8}$, Sahira Tariq ${ }^{3}$,

${ }_{1}^{1}$ Department of Botany, Mohi-ud-Din Islamic University Nerian Sharif, AJK, Pakistan.

${ }^{2}$ Department of Plant Pathology, University of Poonch Rawalakot, AJK, Pakistan.

${ }^{3}$ Department of Botany, University of Poonch Rawalakot, AJK, Pakistan, Pakistan.

${ }^{4}$ Department of Botany, University of AJK Muzaffarabad, AJK, Pakistan.

${ }^{5}$ Department of Entomology Bahauddin Zakariya University, Multan, Pakistan.

${ }^{6}$ Faculty of Veterinary and Animal Sciences, University of Poonch Rawalakot, AJK, Pakistan.

${ }^{7}$ Department of Horticulture, University of Poonch Rawalakot, AJK, Pakistan.

${ }^{8}$ Department of Environmental Sciences and Engineering, Xian University of Architecture and Technology, Xian, Shaanxi, China.

\section{AR T I C L E I N F O}

\section{Article History}

Received: September 28, 2021

Revised: December 13, 2021

Accepted: December 29, 2021

\section{Keywords}

Ethnobotanical

Deforestation

Fidelity Level

Medicinal Plants

\section{A B S T R A C T}

This Ethnobotanical study was aimed to document the indigenous knowledge of medicinal plants of dhirkot district Bagh AJK along with their therapeutic values and ethnophormacological importance. The ethnobotanical data was collected by using the open-ended questionnaire from the local people about the use of medicinal plants. The current study reported three plant species, viz: Sarcoccoca saligna (Ganeera), Rumex hastatus (Chukhri), Cichurium intybus (Kasni) are mainly used for different ailments. The Plant species selected on the basis of used value were subjected to antibacterial activity by using the disc diffusion method. Different statistical techniques were employed to analyze the data of informant consensus factor (ICF), fidelity level (FL), use value (UV) and relative frequency citation (RFC). Current study reported 93 plant species belonging to 46 families and 81 genera for the treatment different ailments like stomach, liver, diabetes, skin, kidney, blood disorders. The most frequent plant part used was leaf $(40 \%)$, followed by fruit (23\%), whole plant (14\%), stem and seeds (8\% each), tuber (4\%) and flower (1\%). Modes of administration were grouped into 7 categories including raw use (30 use citation) followed by decoction (28), powder (14), paste and extract (7) and seeds (1 use citation). Fresh plant material was most preferable method and oral administration was the highly prevalent. The highest RFC value was calculated for the gastro-paresis (0.71) by Zanthoxylum alatum and the highest UV value was calculated by Malia azedarach (0.54) for fever, blood purification. Similarly, Juglans regia, Sarcoccoca saligna and Datura stramonium were show highest fidelity level ( $\mathrm{FL}=100 \%)$. Local communities were highly dependent on the medicinal plants and reported the best therapeutic values for specific disorders. Urgent attention must be needed to conserve the local flora, detailed documentation of indigenous knowledge and phytochemical/pharmacological authentication of different plants used for different diseases.

Corresponding Author: Basharat Mahmood

Email: rajabasharat@upr.edu.pk

(C) The Author(s) 2021. 


\section{INTRODUCTION}

Ethnobotany is the relationships of local inhabitants with their surrounding flora and the term was first used by US botanist John Harsh Berger during 1896. Native knowledge passed through generation after generation is as old local human community buildup and association between organic assortment, social and instructive structures. Plants are important for natives as they provide nutrition, petroleum, wood and yield of the earth (Hameed et al., 2011; Ahmad et al., 2012). The therapeutic plant information is still useful to environmentalist, pharmacologists, taxonomists, watershed and characteristic life chiefs in overhauling the achievement of an area, other than relocation the predictable employments (Mahmood et al., 2011b; Ibrar et al., 2007). It provides names and compile information regarding human and animal health treatment impact by intake of flora (Arshad et al., 2014; Amjad and Arshad, 2014) and improvement in these information through actions social and educational systems (Ghuffar et al., 2018). Concentrates of various plants are used for the dealing of diseases of human in daily health routine (Ahmad et al., 2009) as medications as full plants are used (Muhammad and Khan, 2008) by masses as primary health care (Upton et al., 2016) and is growing (Bernal et al., 2011).

New diseases are emerging, and pathogens have changed their virulence trends from mild to more aggressive which needs extraordinary requirements for latest drugs. Approximately 223,300 plant's seed have been recorded (Ahmad et al., 2009) for their medicinal values. As resistance is improving against latest drugs provided by pharmaceutical companies ethnobotany provides durable way of medication (Newman and Cragg, 2007). Asian countries are incredible world over for their medicinal plant based wealth and its local inference (Patel and Patel, 2012) made through considerable writing in the field of pharmacology and pharmacognosy (Cox, 2000; Chaudhary et al., 2007). Pakistan is rich in assortment of plants that are being used for healing purposes. There are about 6000 species of vascular plants from which 6002000 have been used as conventional medications (Chaudhary et al., 2007) among them 5700 therapeutic (Husain et al., 2008; Hussain et al., 2012; Ahmad et al., 2009; Alam et al., 2011).

The Himalays are affluent values of biodiversity. The Jammu and Kashmir of the western Himalayas has just about 2000 kinds of angiosperms, 12 sorts of
Gymnosperms and 90 sorts of Pteridophytes (Dar and Ejaz-Ul-Islam, 2003). Azad Jammu and Kashmir is specified with a one of a significant biodiversity and is an predictable contribute of remedial plants for local people. Grouped assortment of monetarily basic plants is really rich in Azad Kashmir (Ahmad et al., 2012; Alam et al., 2011). In spite of the way that, couple of endeavors had been made on the usage of native therapeutic plants particularly bushes and trees in expected human administrations by confined networks of Azad Jammu and Kashmir (Mahmood et al., 2012). Limited regions of AJK are wealthy with habitual healing utilization of plants (Qureshi et al., 2007; Mahmood et al., 2011a). Approximately $70 \%$ of therapeutic plant species are assessed (Shinwari et al., 2011). Number of analysts have led ethnobotanical thinks about from region and recorded number of plant type for treatment of different sicknesses (Alam et al., 2011). Shockingly, these investigations were directed qualitatively, and quantitative ethnobotanical studies are uncommon in the zone. In such manner present investigation can be measured as initial exertion to archive native information of herbs, bushes and trees of the Dhirkot and related zone. This examination points not exclusively to record indigenous awareness and to dissect the information by utilizing ethnobotanical indices yet additionally Screen the selected therapeutic plants for antimicrobial activity.

\section{MATERIALS AND METHODS}

Dhirkot area of District Bagh Azad Jammu and Kashmir which is part of western Himalayan section was surveyed. It is around $150 \mathrm{~km}^{2}$ with height ranges from 600-2000 meter over the ocean level lies on latitude $33^{\circ}$ $36^{\prime} \mathrm{N}$ and longitude $73^{\circ}-75^{\prime} \mathrm{E}$. It is bounded on the North by District Muzaffarabad, on the South by District Poonch, on the West by Abbotabad and Murree regions of Pakistan (Figure 1).

Dhirkot is hilly and mountainous area with subtropical to humid temperate type climate. The average maximum temperature during summer is $28{ }^{\circ} \mathrm{C}$ and minimum 24 ${ }^{\circ} \mathrm{C}$ while average maximum temperature during winter is $9.5{ }^{\circ} \mathrm{C}$ and minimum is $5.3{ }^{\circ} \mathrm{C}$ (Figure 2) with precipitation during summer is $85 \mathrm{~mm}$ and winter $35 \mathrm{~mm}$ (Figure 3).

\section{Field surveys and plant identification}

Field studies were carried out during 2016-2017 to collect ethnobotanical information from Dhirkot. During 
survey 120 key nearby witnesses of various statistic report and diverse professions, for example, hakims, agriculturists, and shepherds housewives, were interviewed to collect information. Plant specimens were collected, identified and archived in herbarium at herbarium division of Botany University of Poonch,
Herbarium National Agriculture Research Center (NARC) Islamabad, Pakistan and by contrasting depiction and distributed volumes of Flora of Pakistan. All the voucher specimens were saved in Department of Botany, University of Poonch Rawalakot.

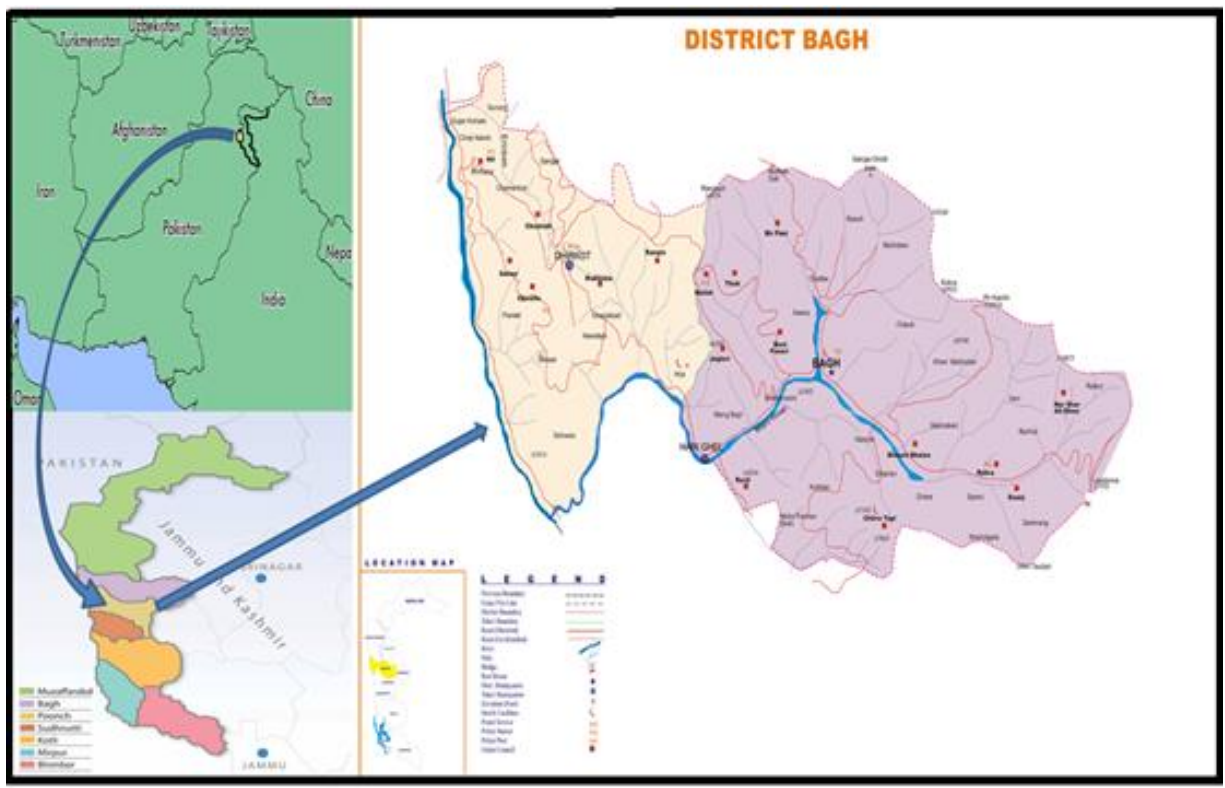

Figure 1. Geographic location of District Bagh (Left), Dhirkot (Study area) Right.

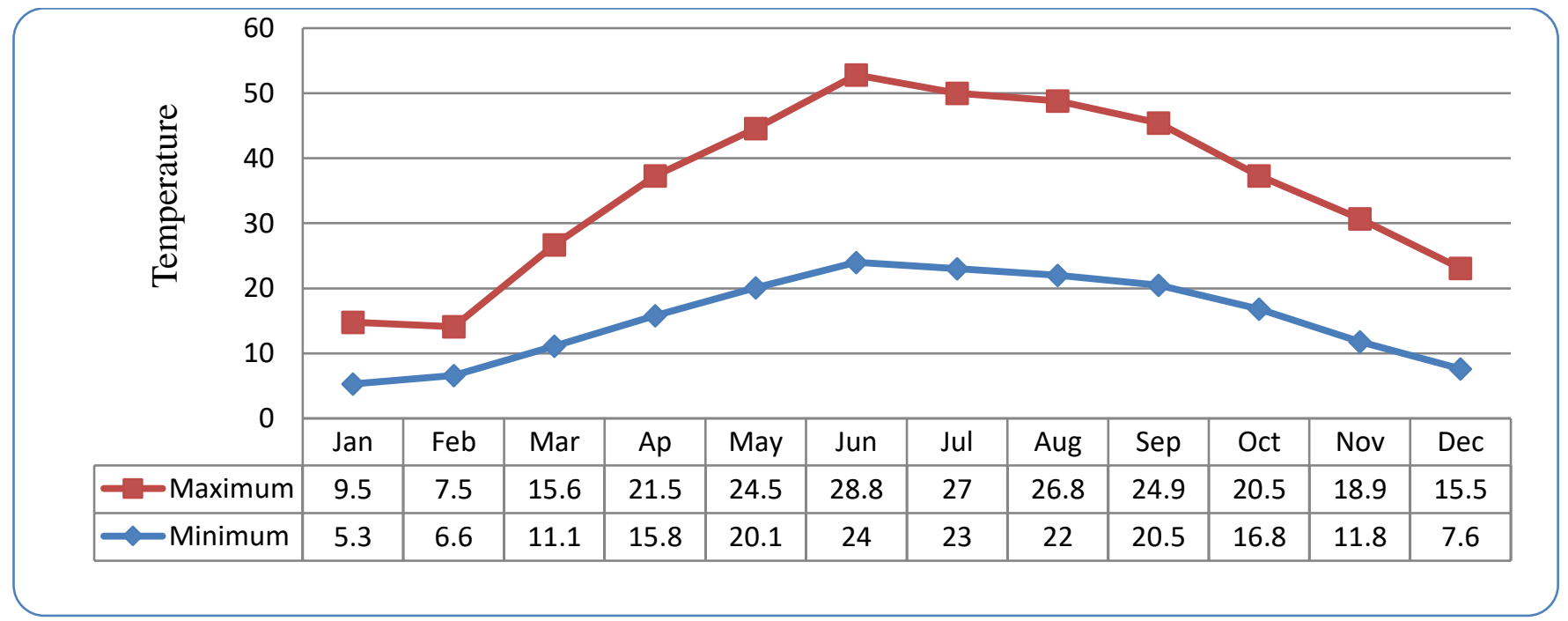

Figure 2. Average minimum and maximum temperature of the year in Dhirkot.

\section{Data Analysis}

The consistency and legitimacy of ethnotherapeutic data were checked and bolstered by various miniaturized scale factual apparatuses i.e., use report (UR), use value (UV), informant consensus factor (ICF), fidelity level (FL) and relative frequency of citation (RFC) with the help of formula given under.

Fidelity Level (FL \%);

$$
\text { FL } \%=\left(\frac{\mathrm{Ip}}{\mathrm{Iu}}\right) 100
$$


Where Ip is the number of informants who independently suggested the use of plants for a particular purpose and $\mathrm{Iu}$ is the total number of informants who mentioned the plants for any use or purpose.

\section{Informant Consensus Factor (ICF)}

Informant consensus factor was calculated by using following formula;

$$
\mathrm{ICF}=\frac{(\mathrm{Nur}-\mathrm{Nt})}{(\mathrm{Nur}-1)}
$$

Where $\mathrm{N}_{\mathrm{ur}}$ is the number of used citation in each category and $\mathrm{N}_{\mathrm{t}}$ is number of species used for specific diseases.

\section{Use value (UV)}

The data was inspected by computing the use value to confirm relative hugeness of species or family for a population and regular therapeutic uses by nearby occupants (Vendruscolo and Mentz, 2006). Use value was calculated by using following formula;

$$
\mathrm{UVi}=\frac{\Sigma \mathrm{Ui}}{(\mathrm{Ni})}
$$

Where $U_{i}$ is number of use by each informer for specific plant species and $\mathrm{N}_{\mathrm{i}}$ is the number of informer interviewed for specific plant species.

\section{Relative frequency of citation (RFC)}

Relative frequency citation was calculated by using following formula;

$$
R F C=\Sigma F C(\text { of all species }) \times 100
$$

Where $(\mathrm{FC})=$ number of informant who cited the medicine/total number of informants interviewed $\times 100$

\section{RESULTS}

\section{Medicinal plants survey}

Current investigation calculated 93 species belonging to 81 genera and 46 families. The prevailing ethnobotanical family is Rosaceae with 11 species, followed by Asteraceae with 7 species and Solanaceae, Lamiaceae, Fabaceae with 5 species each. Out of 93 plant species, 88 species are angiosperms, 3 were Pteridophytes, 1 gymnosperm and 1 mushroom (Figure 3 ). Information stock consist botanical names, families, local names, parts utilized and percentage of informants having medicinal plants information. Ethnomedicinal data showed that these plant species are predominantly used to fix stomach issue, heart sicknesses, diabetes, skin ailments, liver and kidney diseases.

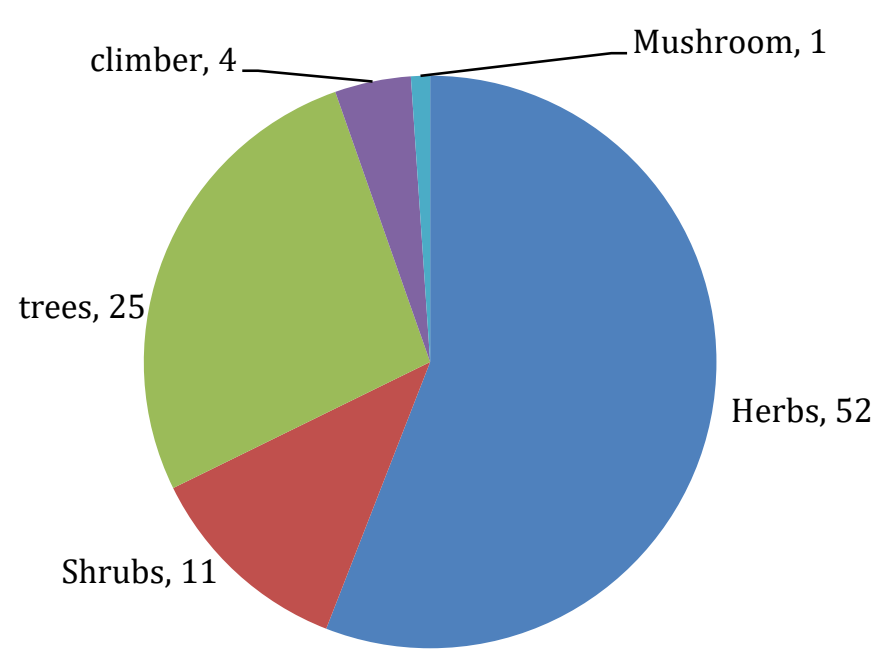

Figure 3. Life form of Ethnobotanical important species of Dhirkot AJK.

\section{Ethnobotany of the area}

Current investigations were analyzed 93 therapeutic plant have a place with 81 genera and 46 families. Out of 93 species were angiosperms, 3 were pteridophytes, 1 was gymnosperms and 1 was mushroom. Living appearance records indicated that 54 species were herbs, 25 were trees, 11 shrubs, 4 climbers and 1 was mushroom. The investigation of plants parts utilized 
demonstrated that leaves (40\%) were the most as often as possible utilized plant parts pursued by natural products (23\%), entire plant (14\%), stem and seeds ( $8 \%$ every), tubers (4\%) and blooms (1\%) (Figure 4). Leaves and fruits are regularly utilized by nearby occupants for the cure of their infirmities as these parts have progressively bioactive compounds when contrasted with different parts.

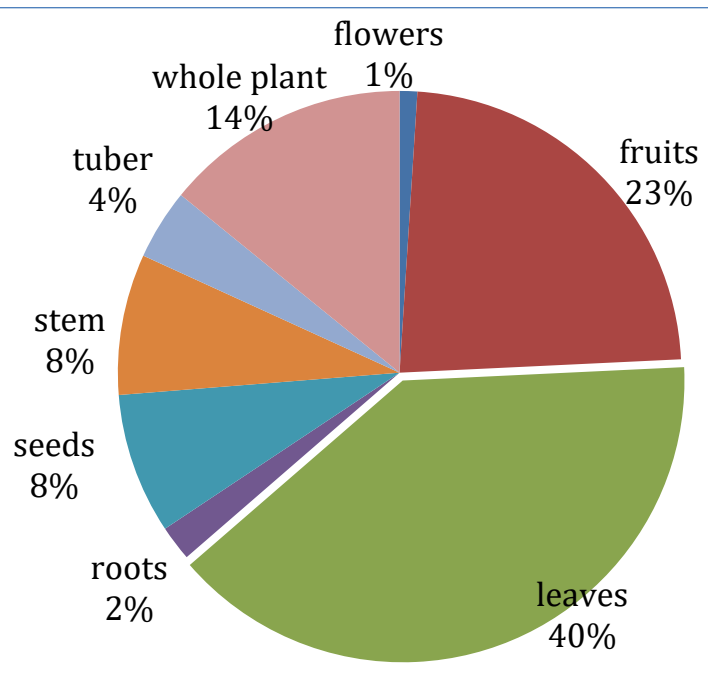

Figure 4. Parts of medicinal plants used for the treatment of diseases in the study area.

\section{Mode of administration}

Method of arrangement and organization are assembled into 7 classes including raw use (30 use references) trailed by decoction (28), powder (14), paste and extract (7 each) and seeds 1 use citation. The method of organization and relevance rely upon sort of disease which is commonly oral and outer.

\section{Medicinal uses of plants}

Among recorded 93 species, 51\% are used as fodder in community, $39 \%$ as food and $23 \%$ as timber. The food plants consist of wildtype fruits, potherbs, brewages, spices, cash plants and dry fruits that provide a portion of the food supplies to people. However; their economic significance is small but is an essential part of the local economy and culture. The accessibility of wild food varies in the diverse seasons. In spring a group of wild herbs are composed that serve as a food article for the people. The most commonly used wild vegetables include Amaranthus viridis L. (Ganhar), Chenopodium album L. (Batwa), Cichorium intybus L. (Kashni), Datura stramonium L. (Datora), Ficus palmate Frossk (Phagoi), Nasturtium officinale L. (chow). These are not only utilized through the spring but also dried for use in later months particularly in winter, when the food deliver is insufficient. The majority of these vegetables are collected in spring or summer and conserved by drying and reserved for additional use in winter (Figure 5). The wild fruits contain Ficus palmate Frossk (Paghoi), Olea ferruginea Wall. ex Aitch. (Kao), Juglans regia L. (Akhrot) and Pyrus pashia L. (Tangie). Fuel wood is one of the mainly significant essential requirements in the area. Even though, the collectors desire deadwood but cut living brushwood or small trees if deadwood is insufficient. It is totally satisfied from the forests. The most chosen wood in the area is oak followed by olea, willow, mulberries and walnuts etc. Moreover, these each and every plant which is otherwise useless is generally exposed to burning as fuel wood.

\section{Quantitative analysis \\ Relative frequency of citation (RFC)}

To survey the most ordinarily utilized plants by nearby population relative frequency of citation was assessed which goes between 0.65 to 0.07 . Greatest Relative frequency of citation was recorded for Zanthoxylum alatum Roxb (0.65), trailed by Allium sativum L., Cichorium intybus L., Sapindus mukorossi Gaertn (0.67 each) and Rumax hastatus D. Wear (0.70). Least frequency of citation was calculated for Spinacia 
oleraceae L. (0.07), Sarcococca saligna Mull. Arg (0.08), Asplenium dalhousiae Hook, Amaranthus viridis L. (0. 09 each) and Cannabis sativa L. (0.1) (Table 1,2).

\section{Use value (UV)}

The consequence of every species was observed by computing use value. Use value extends between 0.54 to 0.10 . Most extreme use value was determined for
Melia azedarach L. (0.54) followed by Coriandrum sativum L. (0.52), Ajuga bracteosa Wall. ex Benth., Berberis lyceum Royle (0.47 each), Artemisia japonica Thunb. and Cichorium Intybus L. (0.46 each). Smallest Use value was calculated for Salix babylonica L., Viburnum grandiflorum Sm., Rosa brunonii Lindle. (0.10 each) followed by Sapindus mukorossi Gaertn and Chenopodium album L. (0.11 each).

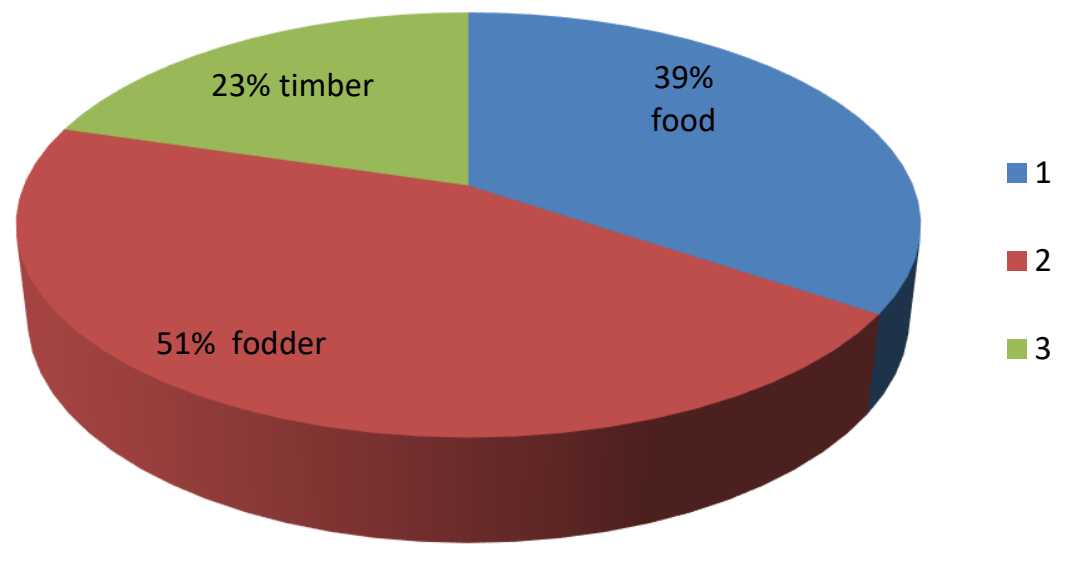

Figure 5. Life form of Ethnobotanical uses.

\section{Fidelity level (FL \%)}

Information was calculated to discover mainly ideal species for the healing of exacting disease by recorded Fidelity level (extends between $100 \%$ to $14 \%$ ). Juglan regia L., Sarcococca Saligna Mull. Arg. and Datura stramonium L. shown (100\%) fidelity level followed by Cynodon dactylon L. Pers. (93.7 \%), Zanthoxylum alatum Roxb (93.5 \%) and Melia azedarach L. (91.66 \%). lowest fidelity level was recorded for Fragaria nubicola Mill. (14\%), followed by Equisetum arvense L. (26\%), Coriandrum sativum L. (32\%), Olea ferruginea Wall. ex. Aitch and Clitoria ternatea L. (35\% each) (Table 1,2).

\section{Informant consensus factor (ICF)}

In light of information got every one of the illnesses were assembled into 14 classes (Table 2). The understanding between witnesses on the utilization of species ranges with consensus values between 0.53 to 0.76). The most consensus value demonstrates greater homogeneity for the cure of illness. The maximum ICF was analyzed for gastrointestinal clutters (0.76). the information gathered from the interviewees the uncovered illnesses were collected in to 14 classes related to genuine systems (14.2). The assessment revealed that there was admission to the use of these species between sources with ascension regards in the estimations of 0.76 and 0.53 . The maximum ICF value was demonstrated for Gastrointestinal disorder (0.76) and infectious disorder (0.53) as minimum value.

\section{Use of phytotherapies}

Late perception demonstrated that larger piece of nearby people were dependent on an arrangement of indigenous plants to fix diverse illnesses. Along with the investigation it was determined that customary data of restorative plants is tied in with disappearing among the young age in the examination district, this is a direct result of the nonattendance of enthusiasm by current social requests. 
Table 1. List of Ethnobotanical flora from Dhirkot with vernacular, life form, part used, use reports, frequency of citation, relative frequency of citation and fidelity level.

\begin{tabular}{|c|c|c|c|c|c|c|c|c|c|c|c|}
\hline \multicolumn{12}{|c|}{ Ethnobotanical uses } \\
\hline Taxon & Vern & $\mathrm{Hb}$ & $\begin{array}{c}\text { Non } \\
\text { Medicinal }\end{array}$ & Pt Used & Mod Ad & Medicinal Uses. & $\mathrm{Ur}$ & UV & $\mathrm{FC}$ & RFC & FL \\
\hline $\begin{array}{l}\text { Abelmoschus } \\
\text { esculentus (L.) Moench } \\
\text { (Malvaceae) }\end{array}$ & Bhindi & $\mathrm{H}$ & Food & Fruit & Raw & Constipation $^{13}$, Inflammation ${ }^{5}$, Diabetes ${ }^{4}$ & 3 & 0.20 & 15 & 0.12 & 86.60 \\
\hline $\begin{array}{l}\text { Achillia millefolium } \mathrm{L} . \\
\text { (Asteraceae) }\end{array}$ & Sultani botti & $\mathrm{H}$ & Fodder & $\begin{array}{l}\text { Whole } \\
\text { Plant }\end{array}$ & Powder & $\begin{array}{l}\text { Tooth cavity }{ }^{33}, \text { Toothache }^{22}, \text { Fever }^{11} \\
\text { Gastro paresis }{ }^{8} \text {, Inflammation }{ }^{4} \text {, ulcer }\end{array}$ & 6 & 0.30 & 51 & 0.43 & 64.70 \\
\hline $\begin{array}{l}\text { Achyranthes aspera } \mathrm{L} . \\
\text { (Amaranthaceae) }\end{array}$ & Puth Kanda & $\mathrm{H}$ & Fodder & Leaves & Extract & $\begin{array}{l}\text { Snake bite, Diuretic }{ }^{2} \text {, Gastroparesis }{ }^{4} \text {, } \\
\text { Hemorroides }^{2} \text {, Pertusis }{ }^{3} \text { Asthma } \\
\text {, }\end{array}$ & 9 & 0.45 & 41 & 0.34 & 56.00 \\
\hline $\begin{array}{l}\text { Adiantum capillus- } \\
\text { veneris } \mathrm{L} . \\
\text { (Pterideaceae) }\end{array}$ & Kakveya & $\mathrm{H}$ & $\begin{array}{l}\text { Food, } \\
\text { Fodder }\end{array}$ & $\begin{array}{l}\text { Whole } \\
\text { Plant }\end{array}$ & Extract & $\begin{array}{l}\text { Diabetes }^{1} \text { Icteric }^{4}, \text { Fever }^{3,} \\
\text { Liver}^{2} \text {,Diuretic } \\
\text { pain Inflamation }\end{array}$ & 7 & 0.37 & 19 & 0.16 & 89.40 \\
\hline $\begin{array}{l}\text { Ajuga bracteosa Wall. } \\
\text { ex Benth } \\
\text { (Lamiaceae) }\end{array}$ & Ratti Booti. & $\mathrm{H}$ & Fodder & Leaves & Paste & $\begin{array}{l}\text { Diabetes }^{6}, \text { Fever }^{7}, \text { Arthritis }^{9}, \text { Gastritis }^{12} \text {, } \\
\text { Anthelminitic }{ }^{1}, \text { Diuretic }^{2} \text { Inflammation } \\
\end{array}$ & 9 & 0.47 & 71 & 0.59 & 71.83 \\
\hline $\begin{array}{l}\text { Allium cepa } \mathrm{L} . \\
\text { (Alliaceae) }\end{array}$ & Piaz & $\mathrm{H}$ & Food & Tuber & Raw & $\begin{array}{l}\text { Diuretic }^{10}, \text { stimulent }^{6}, \text { Wound healing } \\
\\
\text { Angina petoris }\end{array}$ & 9 & 0.45 & 33 & 0.28 & 81.82 \\
\hline $\begin{array}{l}\text { Allium sativum } \mathrm{L} . \\
\text { (Alliaceae) }\end{array}$ & Lahsan & $\mathrm{H}$ & Food & Leaves & Paste & $\begin{array}{l}\text { Septic }^{1}, \text { Asthmatic } \\
\end{array}$ & 7 & 0.39 & 81 & 0.68 & 87.65 \\
\hline $\begin{array}{l}\text { Aloe vera (L) Burm .f. } \\
\text { (Asphodelaceae) }\end{array}$ & Kore & $\mathrm{H}$ & - & Leaves & Gel & Scabies $^{2}$ Inflammation ${ }^{2}$ Arthritis ${ }^{1}$ & 3 & 0.17 & 23 & 0.19 & 91.30 \\
\hline $\begin{array}{l}\text { Amaranthus viridis } \mathrm{L} . \\
\text { (Amaranthaceae) }\end{array}$ & Ganiyar & $\mathrm{H}$ & $\begin{array}{l}\text { Food, } \\
\text { Fodder }\end{array}$ & Seeds & Powder & $\begin{array}{l}\text { Constipation }{ }^{7} \text { Infalamation }{ }^{1} \text { Angina } \\
\text { pectoris }^{1} \text { Hemorrhoides }^{1}\end{array}$ & 4 & 0.20 & 11 & 0.09 & 81.82 \\
\hline $\begin{array}{l}\text { Anethum graveolens L. } \\
\text { (Apiaceae) }\end{array}$ & Soye & $\mathrm{H}$ & Food & Leaves & $\begin{array}{l}\text { Decocti } \\
\text { on }\end{array}$ & $\begin{array}{l}\text { Abdominal Pain }{ }^{3} \text { Appetizer }^{3} \text { Liver }^{2} \\
\text { Diuretic }^{1} \text { Stomachach }\end{array}$ & 5 & 0.26 & 19 & 0.16 & 68.42 \\
\hline $\begin{array}{l}\text { Argyrolobium roseum } \\
\text { (Cambess.) Jaub. \& } \\
\text { Spach (Fabaceae) }\end{array}$ & Khatti/Jandaro & $\mathrm{H}$ & Fodder & $\begin{array}{l}\text { Whole } \\
\text { Plant }\end{array}$ & $\begin{array}{l}\text { Decocti } \\
\text { on }\end{array}$ & $\begin{array}{l}\text { Fever }^{3} \text { Ulcer }^{4} \text { Appetizer }^{2} \\
\text { Weight Gain }{ }^{1} \text { Gastroparesis } \\
\end{array}$ & 3 & 0.16 & 19 & 0.16 & 63.16 \\
\hline $\begin{array}{l}\text { Artemisia japonica } \\
\text { Thunb. } \\
\text { (Asteraceae) }\end{array}$ & Chau & $\mathrm{H}$ & Fodder & & $\begin{array}{l}\text { Decocti } \\
\text { on }\end{array}$ & $\begin{array}{l}\text { Anemia }{ }^{2} \text { Diabetes }^{3} \text { Hypertensyion }^{1} \\
\text { Skin }^{1} \text { Fever }^{2} \text { Diuretic }^{3}\end{array}$ & 6 & 0.55 & 43 & 0.36 & 72.09 \\
\hline
\end{tabular}




\begin{tabular}{|c|c|c|c|c|c|c|c|c|c|c|c|}
\hline $\begin{array}{l}\text { Asplenium dalhousiae } \\
\text { Hook. } \\
\text { (Aspleniceae) }\end{array}$ & Jarri & $\mathrm{H}$ & Fodder & Leaves & Extract & Snake Bite $^{8}$ Wound healing ${ }^{1}$ & 2 & 0.18 & 11 & 0.09 & 63.64 \\
\hline $\begin{array}{l}\text { Bauhinia variegata } \mathrm{L} . \\
\text { Fabaceae) }\end{array}$ & Kalyar & $\mathrm{T}$ & Food & Leaves & Raw & $\begin{array}{l}\text { Gastroparesis }{ }^{2} \text { Ulcer }^{1} \text { Skin3 Angina } \\
\text { Pectoris }^{2} \text { Tuberculosis }^{1} \text { Liver }^{2}\end{array}$ & 6 & 0.33 & 44 & 0.36 & 61.36 \\
\hline $\begin{array}{l}\text { Berberis lycium Royle. } \\
\text { (Berberidiaceae) }\end{array}$ & Sumbloo & $\mathrm{S}$ & Timber & $\begin{array}{c}\text { Stem } \\
\text { and } \\
\text { Fruit }\end{array}$ & Powder & $\begin{array}{l}\text { Diabetes, Hemorrhoids }{ }^{1} \text { bone Healing }{ }^{2} \\
\text { Toothache3 Gastritis }{ }^{2} \text { Icteric1 } \\
\text { Constipation }^{1} \text { Fever }^{1}\end{array}$ & 8 & 0.47 & 71 & 0.59 & 88.73 \\
\hline $\begin{array}{l}\text { Bergenia ciliata (Haw.) } \\
\text { Sternb } \\
\text { (Saxifragaceae) }\end{array}$ & Zakhm-e-Hyat & $\mathrm{H}$ & Fodder & $\begin{array}{l}\text { Roots \& } \\
\text { Leaves }\end{array}$ & Powder & $\begin{array}{l}\text { Fever }^{2} \text { Ulcer }^{1} \text { Tonic }^{2} \\
\text { Hepatitis B } \\
\text { Muscular Pain }{ }^{1} \text { Inflammation Healing } \\
\text { Diorder }\end{array}$ & 8 & 0.42 & 63 & 0.53 & 87.30 \\
\hline $\begin{array}{l}\text { Brassica compestris L. } \\
\text { (Brassicaceae) }\end{array}$ & Sarson & $\mathrm{H}$ & Food & Roots & Powder & Wound Healing ${ }^{2}$ Pertusis $^{2}$ Diabetes ${ }^{4}$ & 3 & 0.17 & 17 & 0.14 & 76.47 \\
\hline
\end{tabular}

Table 2. Informant consensus factor (ICF) for categories of diseases.

\begin{tabular}{|c|c|c|c|c|c|c|}
\hline No & Diseases Categories & $\begin{array}{l}\text { Number of texa } \\
\text { (NT) }\end{array}$ & Taxa used $\%$ age & $\begin{array}{l}\text { Number of use reports } \\
\text { (NUR) }\end{array}$ & $\begin{array}{l}\text { use reports \% } \\
\text { age }\end{array}$ & $\begin{array}{l}\text { icf=nur-nt/nur- } \\
1\end{array}$ \\
\hline 1. & Infection disorder & 47 & 50.00 & 98 & 9.51 & 0.53 \\
\hline 2. & Skin disorder & 24 & 25.53 & 53 & 5.15 & 0.56 \\
\hline 3. & Diabetic & 21 & 22.34 & 51 & 4.95 & 0.60 \\
\hline 4. & Kidney disease & 50 & 53.19 & 126 & 12.23 & 0.61 \\
\hline 5. & Respiratory disorder & 32 & 34.04 & 82 & 7.96 & 0.62 \\
\hline 6. & Cardiac disorder & 16 & 17.02 & 41 & 3.98 & 0.63 \\
\hline 7. & Skeletal disorder & 16 & 17.02 & 47 & 4.56 & 0.67 \\
\hline 8. & Muscular disorder & 4 & 4.26 & 10 & 0.97 & 0.67 \\
\hline 9. & Obesity & 7 & 7.45 & 20 & 1.94 & 0.68 \\
\hline 10. & Liver disease & 23 & 24.47 & 71 & 6.89 & 0.69 \\
\hline 11. & Glandular Disorder & 6 & 6.38 & 19 & 1.84 & 0.72 \\
\hline 12. & Tooth disease & 11 & 11.70 & 39 & 3.79 & 0.74 \\
\hline 13. & Neurological disorder & 5 & 5.32 & 17 & 1.65 & 0.75 \\
\hline 14. & Gastrointestinal disorder & 67 & 71.28 & 271 & 26.31 & 0.76 \\
\hline
\end{tabular}




\section{DISCUSSION}

Ethnoorganic data were archived diverse illnesses, for example, stomach issue, cardiovascular sicknesses, kidney disease, stomach related confusion, blood cleaning, diabetes, skin, liver. Examination of therapeutic plants demonstrated that mainly predominant plant parts were leaves (40\%) for therapeutic use. Likewise, fruit $(23 \%)$, whole plant (14\%), seeds and stem $(8 \%)$, tubers (4\%) and flower (1\%), were utilized as they consist of a lot quantity of bioactive compounds such as flavanoides, alkaloids, potassium, magnesium, calcium and acetic acid (Sumnar, 2000).

The high proportion of medicinal plants used for local health system similar to the findings reported from Districts Mirpur (Mahmood et al., 2011b), Bimber (Muhammad and Khan, 2008), Neelum (Mahmood et al., 2011a), Poonch (Khan et al., 2011) and Muzaffarabad (Saghir et al., 2001). Medicinal plants have been exploited from the areas due to the growing demands of pharmaceutical industries leading to the extinction of these medicinal plant species. Due to this overexploitation, mostly these preferred medicinal plants now found under the shrubby plants and also at mostly not accessible areas of higher altitudes.

Maximum evaluation of RFC demonstrates that larger piece of the observers agreed that these therapeutic plant species are the most wellknown plants in the examination locale and are remarkable to most prominent number of study sources (Husain et al., 2008).

The rule strategy for utilize calculation for regular medications were the oral way of association took following by the relevant appliance, which is in simultaneousness with past ethno plant considers (Lee et al., 2008). The use and association of helpful plants subordinate upon the kind of disease. The specific plant parts and specific proportions of measurement given for the healing of sicknesses depend upon age and physical state of the patients. (Kayani et al., 2014).

High FL of species demonstrates the ordinariness of specific sicknesses in the examination region. The species having high estimation of FL affirms its uniqueness to treat a particular contamination (Shil et al., 2014). Juglan regia, Sarcococcca saligna, Datura stromonium (100\%) that are used to fix snake bite, wound recuperating, corpulence, measles, cardiovascular, diabetes, diuretic, inflammation, cholesterol, loose bowels, sprain, kidney stone, skin illnesses and epitaxis with extremely highest FL\%.

As they consider phytotherapies less reasonable as broke down to present day arrangement or possibly in light of the way that the manner in which more established people trade their drawing closer to the following edge isn't for the most part ensured. Inspite of that, when these older individuals pass away the conventional learning may be immediately broken up (Abebe and Ayehu, 1993).

It was observed that the highest ICF value was recorded 0.76 and the minimum ICF values was demonstrated 0.53 which is same trend as observed $(0.65)$ reported by Cakilcioglu et al. (2011); Akerreta et al. (2007). Species having high citation frequency and source consensus are regarded as financially immense and serve humankind (Shil et al., 2014).

According to Lee et al. (2008) 216 medicinal plants were reported from Province Yunnan of South-West China. From these 216 plant species two plant species have same uses viz. Phylanthus emblica while eight plant species with different use viz. Alstonia scholaris, Carthamus tinctorius, Eclipta prostrata, Buddleja asiatica, Solanum nigrum and Trianthema portalacastrum. Twenty nine different plant species were reported from Northern Australia having one plant species with the same uses as reported in the current study viz. Achyranthus aspera and one plant species with different uses viz. Ageratum conyzoides as reported in the present study (Bradacs et al., 2011).

\section{CONCLUSION}

The current research consisting essentially to the ethnomedicinal knowledge and determines that therapeutic plants are abundant in Dhirkot area of District Bagh. Therefore, more examination is projected to survey remedial plants culture and to find out energetic antimicrobial compound in these therapeutic plants. Anthropogenic activities like indiscreet removal of therapeutic plants, deforestation, yearly fire practices and lack of awareness are the fundamentals which breaking down therapeutic vegetation as well as universal floral assets.

\section{REFERENCES}

Abebe, D. and A. Ayehu. 1993. Medicinal plants and enigmatic health practices of Northern Ethiopia. 
Biological Science and Plant Ethnophormocolgy, 54: 162-65.

Ahmad, I., M. S. A. Ahmad, M. Hussain, M. Hameed, M. Y. Ashraf and M. Koukab. 2009. Spatio-temporal effects on species classification of medicinal plants in Soone valley of Pakistan. International Journal of Agricultural and Biology, 11: 64-68.

Ahmad, K. S., W. K. Kayani, M. Hameed, F. Ahmad and T. Nawaz. 2012. Floristic diversity and ethnobotany of senhsa, district Kotli, Azad Jammu \& Kashmir (Pakistan). Pakistan Journal of Botany, 44: 195201.

Akerreta, S., R. Y. Cavero and M. I. Calvo. 2007. First comprehensive contribution to medical ethnobotany of Western Pyrenees. Journal of ethnobiology and ethnomedicine, 3: 1-13.

Alam, N., Z. Shinwari, M. Ilyas and Z. Ullah. 2011. Indigenous knowledge of medicinal plants of Chagharzai valley, District Buner, Pakistan. Pakistan Journal of Botany, 43: 773-80.

Amjad, M. S. and M. Arshad. 2014. Ethnobotanical inventory and medicinal uses of some important woody plant species of Kotli, Azad Kashmir, Pakistan. Asian Pacific Journal of Tropical Biomedicine, 4: 952-58.

Arshad, M., M. Ahmad, E. Ahmed, A. Saboor, A. Abbas and S. Sadiq. 2014. An ethnobiological study in Kala Chitta hills of Pothwar region, Pakistan: Multinomial logit specification. Journal of ethnobiology and ethnomedicine, 10: 1-17.

Bernal, J., J. Mendiola, E. Ibáñez and A. Cifuentes. 2011. Advanced analysis of nutraceuticals. Journal of pharmaceutical and biomedical analysis, 55: 75874.

Bradacs, G., J. Heilmann and C. S. Weckerle. 2011. Medicinal plant use in Vanuatu: A comparative ethnobotanical study of three islands. Journal of Ethnopharmacology, 137: 434-48.

Cakilcioglu, U., S. Khatun, I. Turkoglu and S. Hayta. 2011. Ethnopharmacological survey of medicinal plants in Maden (Elazig-Turkey). Journal of Ethnopharmacology, 137: 469-86.

Chaudhary, M. I., H. Qing, P. G. Xiao and Y. Cheng. 2007. Clematis huchouensis T AMURA: A traditional Chinese herbal medicine and its quality control using a high performance liquid chromatography technique. Biological and Pharmaceutical Bulletin, 30: 165-68.
Cox, P. A. 2000. Will tribal knowledge survive the millennium? Science, 287: 44-45.

Dar, M. and Ejaz-Ul-Islam. 2003. Ethnobotanical uses of plants of Lawat district Muzaffarabad, Azad Jammu and Kashmir. Asian Journal of Plant Sciences, 2: 680-82.

Ghuffar, S., G. Irshad, F. Zhai, A. Aziz, H. M. A. M. Asadullah, N. Mehmood, H. Yang, A. Bashir, M. Z. Ahmed and M. F. Aslam. 2018. First report of Fusarium proliferatum causing fruit rot of grapes (Vitis vinifera) in Pakistan. International Journal of Phytopathology, 7: 85-88.

Hameed, M., M. Ashraf, F. Al-Quriany, T. Nawaz, M. S. A. Ahmad, A. Younis and N. Naz. 2011. Medicinal flora of the Cholistan desert: A review. Pakistan Journal of Botany, 43: 39-50.

Husain, S. Z., R. N. Malik, M. Javaid and S. Bibi. 2008. Ethonobotanical properties and uses of medicinal plants of Morgah biodiversity park, Rawalpindi. Pakistan Journal of Botany, 40: 1897-911.

Hussain, P. R., M. A. Dar and A. M. Wani. 2012. Effect of edible coating and gamma irradiation on inhibition of mould growth and quality retention of strawberry during refrigerated storage. International journal of food science \& technology, 47: 2318-24.

Ibrar, M., F. Hussain and A. Sultan. 2007. Ethnobotanical studies on plant resources of Ranyal hills, District Shangla, Pakistan. Pakistan Journal of Botany, 39: 329-236.

Kaya, G. 2006. Discussion of P\&P model used for estimating option value of forest ecosystems as medicinal plant resources. Journal of the Bartın Faculty of Forestry, 8: 23-32.

Kayani, S., M. Ahmad, M. Zafar, S. Sultana, M. P. Z. Khan, M. A. Ashraf, J. Hussain and G. Yaseen. 2014. Ethnobotanical uses of medicinal plants for respiratory disorders among the inhabitants of Gallies-Abbottabad, Northern Pakistan. Journal of Ethnopharmacology, 156: 47-60.

Khan, M. A., S. A. Khan, M. A. Qureshi, G. Ahmed, M. A. Khan, M. Hussain and G. M. Ghulam. 2011. Ethnobotany of some useful plants of Poonch Valley Azad Kashmir. Journal of Medicinal Plants Research, 5: 6140-51.

Lee, S., C. Xiao and S. Pei. 2008. Ethnobotanical survey of medicinal plants at periodic markets of Honghe Prefecture in Yunnan Province, SW China. Journal 
of Ethnopharmacology, 117: 362-77.

Mahmood, A., A. Mahmood and R. N. Malik. 2012. Indigenous knowledge of medicinal plants from Leepa valley, Azad Jammu and Kashmir, Pakistan. Journal of Ethnopharmacology, 143: 338-46.

Mahmood, A., R. N. Malik, Z. K. Shinwari and A. Mahmood. 2011a. Ethnobotanical survey of plants from Neelum, Azad Jammu and Kashmir, Pakistan. Pakistan Journal of Botany, 43: 105-17.

Mahmood, A., R. A. Qureshi, A. Mahmood, Y. Sangi, H. Shaheen, I. Ahmad and Z. Nawaz. 2011b. Ethnobotanical survey of common medicinal plants used by people of district Mirpur, AJK, Pakistan. Journal of Medicinal Plants Research, 5: 4493-98.

Muhammad, I. C. and M. Khan. 2008. An ethnomedicinal inventory of plants used for family planning and sex diseases in Samahni valley, Pakistan. Indian Journal of Traditional Knowledge, 7: 277-83.

Newman, D. J. and G. Cragg. 2007. Natural products as sources of new drugs over the late 25 years. Journal of Natural Product, 70: 466-77.

Patel, P. and M. Patel. 2012. Ethnogynaecological uses of plants from Gujarat, India. Bangladesh Journal of Plant Taxonomy, 19: 93-94.

Qureshi, R. A., M. A. Ghufran, S. A. Gilani, K. Sultana and
M. Ashraf. 2007. Ethnobotanical studies of selected medicinal plants of Sudhan Gali and Ganga Chotti hills, district Bagh, Azad Kashmir. Pakistan Journal of Botany, 39: 2275-83.

Saghir, I. A., A. A. Awan, S. Majid, M. A. Khan, S. J. Qureshi and S. Bano. 2001. Ethnobotanical studies of Chikar and its allied areas of district Muzaffarabad Pakistan. OnLine Journal of Biological Sciences 1: 1165-70.

Shil, S., M. D. Choudhury and S. Das. 2014. Indigenous knowledge of medicinal plants used by the Reang tribe of Tripura state of India. Journal of Ethnopharmacology, 152: 135-41.

Shinwari, S., R. Qureshi and E. Baydoun. 2011. Ethnobotanical study of Kohat pass Pakistan. Pakistan Journal of Botany, 43: 135-39.

Upton, R., A. Graff, G. Jolliffe, R. Länger and E. Williamson. 2016. American herbal pharmacopoeia: botanical pharmacognosy-microscopic characterization of botanical medicines. CRC Press.

Vendruscolo, G. S. and L. A. Mentz. 2006. Levantamento etnobotânico das plantas utilizadas como medicinais por moradores do bairro Ponta Grossa, Porto Alegre, Rio Grande do Sul, Brasil. Iheringia, Série Botânica., 61: 83-103.

Publisher's note: EScience Press remains neutral with regard to jurisdictional claims in published maps and institutional affiliations.

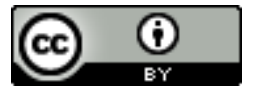

Open Access This article is licensed under a Creative Commons Attribution 4.0 International License, which permits use, sharing, adaptation, distribution and reproduction in any medium or format, as long as you give appropriate credit to the original author(s) and the source, provide a link to the Creative Commons license and indicate if changes were made. The images or other third-party material in this article are included in the article's Creative Commons license, unless indicated otherwise in a credit line to the material. If material is not included in the article's Creative Commons license and your intended use is not permitted by statutory regulation or exceeds the permitted use, you will need to obtain permission directly from the copyright holder. To view a copy of this license, visit http://creativecommons.org/licenses/by/4.0/. 